\title{
The Poverty Index Mapping in the Barlingmascakeb Area in 2019
}

\author{
Fitroh Amaniah ${ }^{1}$, Fani Setiati ${ }^{1}$, Mya Dwi Rostika ${ }^{2}$ and Ratih Fitria Putri ${ }^{1 *}$ \\ ${ }^{1}$ Department of Environmental Geography, Faculty of Geography, Universitas Gadjah Mada, Jl. Sekip Utara, Bulak Sumur, \\ Yogyakarta 55281, Indonesia \\ ${ }^{2}$ Department of International Relations, Faculty of International Relations, Daito Bunka University, Japan
}

\begin{abstract}
Poverty is one of the serious problems in the national development process in Indonesia. Development basically aims to lead to a better situation and create a just and prosperous society. In the concept of Population-Centered Development, populations are not only treated as "objects" but also "subjects" of development. However, the incessant development carried out in various regions has not fully brought the welfare of the population. One of them is Central Java province which is a poverty pocket in Indonesia with a poverty percentage of 10.80 in 2019. Especially in the Barlingmascakeb area, namely Banjarnegara, Purbalingga, Banyumas, Cilacap, Kebumen, in the same year the percentage of poverty was relatively higher, respectively 14.76 percent, 15.03 percent, 12.53 percent, 10,73 percent, and 16.82 percent. This study aims to examine the poverty index spatially in the Barlingmascakeb area in 2019 and find out the dominant indicators that determine the poverty index as one of the evaluation materials for the development process in the region. The data used to measure the poverty index is to use indicators on several dimensions of the Population-Centered Development Index (PCDI). The participation dimension is represented by the EPR (Employment to Population Ratio) indicator and the level of labor force participation rate; the dimension of partiality represented by the percentage of RREB (Regional Revenue and Expenditure Budget) for poverty reduction and other indicators related to poverty, namely income per capita. The spatial distribution of the poverty index is known through Geographic Information System (GIS) software.
\end{abstract}

\section{Introduction}

Poverty is a population problem that is familiar to developing countries, one of which is Indonesia. According to [1] poverty is one of the serious problems in the national development process in Indonesia. Poverty is considered as a form of development problem due to the negative impact of unbalanced economic growth so that it widens the income gap between communities and between regions [2]. The poverty of an area is an indicator of the success of the development of an area because the lower the poverty level of an area indicates an increase in the welfare of the population.

Barlingmascakeb is one of the regionalization areas in Central Java which includes Cilacap Regency, Banyumas Regency, Purbalingga Regency, Banjarnegara Regency, and Kebumen Regency. This is regulated in regional regulation number 6 of 2010 concerning the Spatial and Regional Planning of Central Java Province. The goal is to establish communication, coordination, and cooperation between one region and another so that equitable development can be achieved [3]. According to [4] states that the Barlingmascakeb area has a fairly high gini ratio index level. Rapid economic growth that is not accompanied by economic equality has the potential to lead to higher inequality and poverty.
Based on data from the Central Bureau of Statistics [5] from 2016 to 2019, the percentage of poverty in the Barlingmascakeb area tends to decrease from year to year (Fig. 1). In 2019, the poverty rate of each district in Barlingmascakeb was 14.76 percent respectively; 15.03 percent; 12.53 percent; 12.53 percent; 10.73 percent, and 16.82 percent. Kebumen Regency is the district with the highest poverty rate among other districts in Barlingmascakeb, while the lowest poverty is in Cilacap Regency. According to [4], Cilacap Regency is included in the main industrial area in Central Java after Semarang and Surakarta. Although the percentage of poverty decreases every year, there are still many people who live below the poverty line [6].

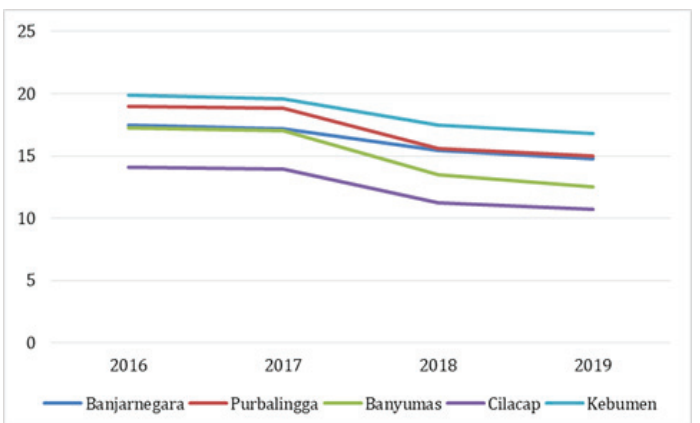

Fig.1. Percentage of Poverty by District in the Barlingmascakeb Area 2016-2019

Source: Central Bureau of Statistics, (2021)

\footnotetext{
*Corresponding author: ratihfitria.putri@ugm.ac.id
} 
There are many factors that can affect poverty in an area. Gross Regional Domestic Product (GRDP) is one of the factors that reflects the productivity and income of the community in an area. If GRDP increases, productivity and income will increase which will then be able to reduce the number of poor people [7]. In addition, the participation of the working labor force and the availability of employment opportunities have an effect on poverty. Narrow job opportunities causing inequality in the distribution of income and will further create a high level of poverty [8]. On the other hand, the Regional Revenue and Expenditure Budget (RREB) poverty is one step to alleviate poverty [9].

GRDP per capita, employment to population ratio, labor force participation rate, and the percentage of RREB in poverty reduction are some of the variables that make up a population-oriented development index that can be used to determine the magnitude of the poverty index in an area, including poverty in Barlingmascakeb. According to [10], populationcentered development is a development concept that places the population as the center of development, namely as subject and object. The poverty index which refers to population-centered development is oriented to population participation in accordance with potential development so as to improve the quality of the population which is the goal of development [11].

Based on the explanation above, the purpose of this research is to examine the poverty index spatially in the Barlingmascakeb area in 2019 and find out the dominant indicators that determine the poverty index as one of the evaluation materials for the development process in the region. The existence of accurate poverty information in the Barlingmascakeb area is expected to be able to succeed in poverty reduction programs and direct development that is more focused and on target.

\section{Method}

\subsection{Location}

Location of this research is in the Barlingmascakeb area (Banjarnegara, Purbalingga, Banyumas, Cilacap, and Kebumen). Barlingmascakeb is one of eight strategic areas in Central Java with fast economic growth. Barlingmascakeb's economic growth rate is the second largest after the Bregas area (Brebes, Tegal, and Slawi). However, the level of welfare among districts in this region is not evenly distributed [12]. In addition, the poverty rate in the Barlingmascakeb area in 2019 was still higher than the Central Java province poverty rate of 9.20 percent. Based on these things, the Barlingmascakeb area was chosen as the research location to determine the poverty index in 2019 .

\subsection{Data}

This study uses secondary data in the form of employment data, GRDP data, population data, and RREB data for poverty reduction in each district of the
Barlingmascakeb area. 2019. These data are sourced from the publications of the Central Bureau of Statistics (CBS) at the district/city level of Barlingmascakeb and $\mathrm{CBS}$ at the National level. Data processing is carried out using Microsoft Excel to calculate the employment to population ratio index, labor force participation rate (LFPR), and GRDP per capita by district/city in the Barlingmascakeb area. From these indices, a poverty index between districts in Barlingmascakeb was obtained in 2019. The map of the distribution of poverty in the Barlingmascakeb area was processed using ArcGIS software. The results of data processing were analyzed descriptively qualitatively by explaining the poverty index in the Barlingmascakeb area.

\subsection{Research Design}

This research begins with data collection from statistics data from CBS and shapefile data from the geospatial information agency. The next stage is to process the data to calculate the poverty index between districts in the Barlingmascakeb area. The last is the data analysis stage which is carried out descriptively to explain the phenomenon of poverty that occurs in the Barlingmascakeb area. The output of this research is in the form of tables, graphs, and maps of the distribution of the poverty index in Barlingmascakeb district. The design of this research is shown in the following flow chart (Fig. 2)

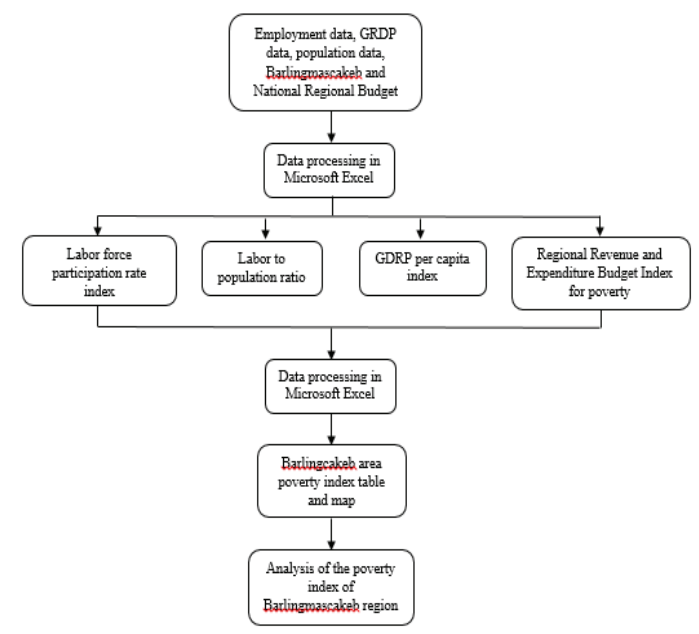

Fig. 2. Research flow chart.

\section{Result and Discussion}

Poverty is a classic problem in developing countries which to overcome it must be investigated from the smallest unit (based on data availability), namely the district. The trend of poverty that continues to decline in Indonesia is the result of the government's efforts to alleviate the problem of poverty which must be appreciated, including in Central Java Province, which is one of the pockets of poverty in Indonesia. The reduction in the poverty rate at the national and provincial levels that is not matched by a decrease at the district level which is the smallest unit will make the 
poverty problem vulnerable to increase and of course not investigate the problem from its root. This can be seen in the Barlingmascakeb area, which is an area that will be the center of growth in Central Java, which has a poverty rate that tends to decrease in each district but the figure is still above the province, this shows that development policies and poverty alleviation programs have not been successful and a development evaluation is needed. in each district in the Barlingmascakeb area.

One of the indicators that can be used as evaluation material for improving the quality of development policies and programs as well as poverty alleviation is the poverty index. The poverty index consists of several indicators, namely employment to population ratio (EPR), labor force participation rate (LFPR), percentage of RREB for poverty reduction, and GRDP per capita. Based on Table 1, the highest and lowest employment to population ratios in the Barlingmascakeb area are Banjarnegara Regency and Cilacap Regency, namely 68.91 and 57.70 . The interpretation of this figure is that in 2019 in Banjarnegara Regency of 100 people aged 15 years and over there were around 69 people who worked and in 2019 in Cilacap Regency of 100 people aged 15 years and over there were around 58 people who worked. While the employment to population ratio of Central Java Province in 2019 was 65.47. This means that of the five districts in the Barlingmascakeb area, there are only two districts that are above the provincial figure, namely Banjarnegara Regency at 68.91 and Purbalingga Regency at 66.07.

The same is true for indicators of the level of labor force participation. Only two districts in the Barlingmascakeb area have LFPR figures above the province, namely Banjarnegara Regency and Purbalingga Regency. The two indicators, namely EPR and LFPR are indicators related to labor. This means that these districts must formulate policies that can encourage participation and employment indicators such as the preparation of quality labor resources, expansion of job opportunities, easy access to capital and markets, as well as improving the quality of infrastructure, licensing, and investment. An increase in the ratio of the workforce and the level of labor force participation will affect the level of individual income and the welfare of society in general through the multiplayer effect arising from the expansion of employment opportunities.

Table 1. Employment to Population Ratio, Labor Force Participation Rate, Percentage of RREB for Poverty Reduction, and GRDP per Capita by District of Barlingmascakeb Area in 2019.

\begin{tabular}{lccccccccc}
\hline $\begin{array}{c}\text { Employment } \\
\text { Regency/City }\end{array}$ & $\begin{array}{c}\text { Le Population force } \\
\text { Ratio }\end{array}$ & $\mathrm{i}$ & $\begin{array}{c}\text { pabticipation } \\
\text { rate }\end{array}$ & $\begin{array}{c}\text { Regional } \\
\text { revenue and } \\
\text { expenditure } \\
\text { budget for } \\
\text { poverty (\%) }\end{array}$ & $\begin{array}{c}\text { Gross Regional } \\
\text { Domestic } \\
\text { Product per } \\
\text { capita (million) }\end{array}$ & i & $\begin{array}{c}\text { Poverty } \\
\text { Index }\end{array}$ \\
\hline Banjarnegara & 68,91 & 0,42 & 71,78 & 0,42 & 45,63 & 0,73 & 23,40 & 0,02 & 0,40 \\
Purbalingga & 66,07 & 0,36 & 70,33 & 0,38 & 49,47 & 0,79 & 26,68 & 0,03 & 0,39 \\
Banyumas & 64,67 & 0,33 & 67,50 & 0,32 & 53,27 & 0,86 & 31,87 & 0,03 & 0,38 \\
Cilacap & 57,70 & 0,17 & 62,37 & 0,19 & 51,62 & 0,83 & 66,06 & 0,08 & 0,32 \\
Kebumen & 61,91 & 0,27 & 65,53 & 0,27 & 52,29 & 0,84 & 23,35 & 0,02 & 0,35 \\
\hline
\end{tabular}

Percentage of Regional Revenue and Expenditure Budget (RREB) for poverty reduction programs in each district in the Barlingmascakeb area has exceeded the Central Java provincial government's budget allocation for poverty reduction, which is $45.23 \%$. This is good for accelerating poverty alleviation in each district of the Barlingmascakeb area. The district with the highest RREB allocation for poverty reduction is Banyumas Regency, which is $53.27 \%$, while the district with the lowest RREB allocation for poverty reduction is Banjarnegara Regency, which is $45.63 \%$. The higher the RREB allocation for poverty alleviation in the district, the more programs that can be run to reduce poverty levels.

The highest GRDP per capita in the Barlingmascakeb area, namely Cilacap Regency, far exceeds other regencies at 66.06 million and the lowest is Kebumen Regency at 23.35 million. This shows the need to increase efforts to increase regional income which is still low, especially in Kebumen Regency, Banjarnegara Regency, and Purbalingga Regency by utilizing and maximizing leading sectors and developing potential sectors.

Judging from the large value of the indicators that make up the poverty index in the Barlingmascakeb area, each index has a fairly high gap, especially the RREB indicator with GRDP per capita (Fig. 3). The Barlingmascakeb area has a relatively high RREB for poverty alleviation, but on the other hand the level of per capita income is still very low. Thus, in terms of poverty alleviation in the Barlingmascakeb area, it is necessary to prioritize indicators that are still low in order to accelerate poverty alleviation.

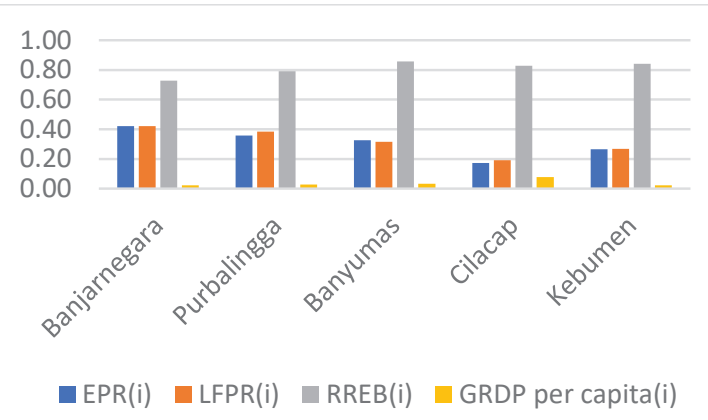

Fig. 3. Employment to Population Ratio Index, Labor Force Participation Rate (LFPR) Index, Percentage Index of RREB for Poverty Reduction, and GRDP Index per Capita by District of Barlingmascakeb Area in 2019.

Based on the calculation results show that the highest poverty index in the Barlingmascakeb area is in Banjarnegara Regency at 0.40 and the lowest poverty index is in Cilacap Regency at 0.32 (Table 2). This is influenced by the high employment to population ratio index and the labor force participation rate of Banjarnegara Regency and indirectly also shows the effectiveness of employment policies for poverty reduction in this district even though the percentage of RREB for poverty reduction is the smallest compared to other districts in the Barlingmascakeb area. The opposite occurs in Cilacap Regency which has a relatively high percentage of the APBD for poverty 
reduction and the highest per capita income, but this is not matched by an increase in the quality of employment which is the main element driving the regional economy as well as the strongest element for poverty alleviation which can be seen from the EPR and LFPR indicators. The lowest LFPR in the Barlingmascakeb area makes Cilacap Regency the district with the lowest poverty index in the Barlingmascakeb area.

Table 2. Inter-Regency Poverty Index in the Barlingmascakeb Area in 2019

\begin{tabular}{lcl}
\hline Regency/City & $\begin{array}{c}\text { Poverty } \\
\text { Index }\end{array}$ & Class \\
\hline Banjarnegara & 0,40 & Moderate \\
Purbalingga & 0,39 & Moderate \\
Banyumas & 0,38 & Moderate \\
Cilacap & 0,32 & Low \\
Kebumen & 0,35 & Moderate \\
\hline
\end{tabular}

The distribution of the poverty index in the Barlingmascakeb area is relatively uniform with a moderate poverty index in four districts, namely Banjarnegara, Purbalingga, Banyumas and Kebumen Regencies. Meanwhile, Cilacap Regency has a low poverty index (Fig. 4). The higher the poverty index, the easier it is to get out of the poverty trap.

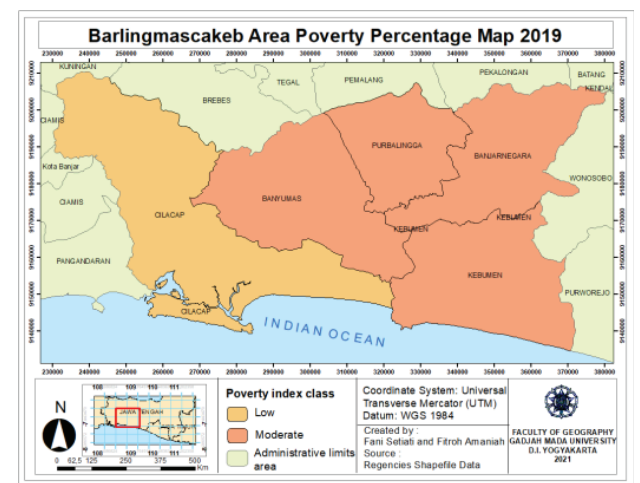

Fig. 4. Map of the Distribution of Poverty in the Barlingmascakeb Area in 2019

The current poverty index shows that there is still homework for the government to continue to improve poverty alleviation programs in the Barlingmascakeb area. Each district has different characteristics, so in poverty alleviation it is necessary to consider the factors that affect poverty based on the indicator values that make up the poverty index in the district concerned. Thus, the poverty alleviation program in the Barlingmascakeb area run by the government will be more targeted.

\section{Conclusion}

Based on the explanation above, it can be concluded that:

1. Spatially, the poverty index in the Barlingmascakeb area is in the moderate range, except for Cilacap Regency which has a low poverty index. The poverty index of each district in the Barlingmascakeb area is 0.40 , respectively; $0.39 ; 0.38 ; 0.32$; and 0.35 .

2. The most dominant factor influencing the formation of the poverty index in the Barlingmascakeb area is income per capita (GRDP per capita) which is still low in each district. The high percentage index of the RREB indicates that the government is aware that it is quite good in terms of alleviating poverty problems in the Barlingmascakeb area.

\section{Suggestions}

From this study, the authors have inputs that need to be considered by the government of Barlingmascakeb area, namely:

In terms of formulating poverty alleviation policies in the Barlingmascakeb area, especially in Cilacap and Kebumen Regencies, it is necessary to prioritize programs for expanding employment opportunities and improving the quality of human resources in order to absorb the workforce. which is much more. Some things that can be done include opening skills training, courses, improving educational facilities, empowering local communities, and others. Improvements in the labor market system will directly increase people's real incomes which can gradually reduce poverty.

\section{References}

1. Solikatun, Supono, Masruroh, Y., \& Zuber, A., Kemiskinan Dalam Pembangunan. Jurnal Analisa Sosiologi, 3(1), 70-90 (2014)

2. Rahman, P.A., et al., Kemiskinan Dalam Perspektif Ilmu Sosiologi. Jurnal Pendidikan Tambusai, 3(6), 1542-1548 (2019)

3. Bachtiar, P. A. Analisis Pengaruh Tenaga Kerja Terdidik, Tenaga Kerja Tidak Terdidik, Dan Realisasi Belanja Modal Pemerintah Terhadap Pertumbuhan Ekonomi (Studi Kasus:

Barlingmascakeb, Subosukawonosraten, dan Kedungsepur). Universitas Diponegoro (2013)

4. Hapsari, S. H., Analisis Ketimpangan Pembangunan dan Pertumbuhan Ekonomi Antar Kabupaten di Kawasan Barlingmascakeb Tahun 2010-2016, Universitas Muhammadiyah Yogyakarta (2018)

5. Badan Pusat Statistik (BPS), Persentase Penduduk Miskin Menurut Kabupaten / Kota (Persen), 20192020, Diakses pada tanggal 17 Juni 2021 di https://www.bps.go.id/indicator/23/621/1/persenta se-penduduk-miskin-menurut-kabupaten-kota.html (2021)

6. Badan Pusat Statistik (BPS), Profil Kemiskinan di Indonesia Maret 2019, BPS (2019)

7. Wijaya, H., Istiqomah, I., \& Arintoko, A., Analisis Faktor - Faktor yang Mempengaruhi Kemiskinan (Studi Kasus di Kabupaten Banjarnegara, Cilacap, Purbalingga, Kebumen, dan Banyumas), 
Jurnal Ilmiah Universitas Batanghari Jambi, 20 (2), 451 (2020)

8. Tambunan, T., Perekonomian Indonesia: Teori dan Temuan Empiris, Ghalia Indonesia (2001)

9. Koestedjo, E. H., Strategi Penanggulangan Kemiskinan Daerah Kabupaten Gresik Tahun 2017, Journal.Uwks.Ac.Id, 18 (1) (2018)

10. Tjiptoherijanto, P., Menuju Pembangunan Berwawasan Kependudukan. Jurnal Populasi, 11 (1) (2000)

11. Saputra, W., Kebijakan Prespektif Dalam Pembangunan Nasional Yang Berwawasan Kependudukan, (2012)

12. Sutrisno, A., Analisis Ketimpangan Pendapatan Dan Pengembangan Sektor Unggulan Di Kabupaten Dalam Kawasan Barlingmascakeb Tahun 2007-2010. Economics Development Analysis Journal, 1(1) (2012) 